\title{
Presentation Culture in the Digital Age: Online Identity Representation on Social Media
}

\author{
Agus Purnomo Ahmad Putikadyanto ${ }^{1 *}$, Iswah Adriana ${ }^{2}$, Agik Nur Efendi ${ }^{3}$ \\ ${ }^{123}$ Indonesian Language Education Study Program, Institute of Islamic Religion Madura \\ "Corresponding author.Email: aguspurnomo@iainmadura.ac.id
}

\begin{abstract}
Presentation culture relates to a habit or lifestyle that involves presenting themselves on social media. It appears to have gained popularity in recent times. Users can employ multiple, multimodal resources in the expression of their identity due to the recent technological capabilities of social media. No one is exempt from using Instagram as a social media platform. Instagram allows users to promote themselves in a variety of ways, including images, videos, and words. This study aims to examine Instagram users' online identity-building strategy, as well as the visual, enumerative, and self-labelling practices that exist, as well as the creative words that appear. Speeches, words, and videos of Instagram influencers were used as data sources for this study. In furthermore, the language is analyzed to identify Instagram users' online identity-building strategies, as well as types of visual, enumerative, and self-labelling practices, and creative words that arise. As a result, the strategies of Instagram social media users in Indonesia to build online identity are diverse. The same applies to visual, enumerative, and self-labelling practices. However, Instagram social media users are trying to form the self-labelling that many people want / desire. Creative words that appear are abbreviations, additions, acronyms, and cultural acculturation. Identity on social media Instagram can be different from the real identity because identity on social media is not only about who we are but also how other people expect and who we want for others.
\end{abstract}

Keywords: Presentation Culture, Online Identity, Social media.

\section{INTRODUCTION}

A new habit has emerged in the digital era, namely the habit of presenting oneself on social media. These habits can be presented through selfies, photos with famous people, photos with prestige values, status updates, and so on. This habit of presenting oneself is called presentation culture [1]; [2]. Technological developments provide the ability of social media to present opportunities for its users to utilize various multimodal resources in expressing their identity [3]; [4]; [5]. Social media users can express their online identity through the written word or through display pages which can be a combination of images, videos, written and spoken language, or a combination of these.

Online identity can be interpreted as a self-image of internet users in online media or sites. This online identity has been the focus of research since the birth of the internet until now, from face-to-face communication to online interaction [6]). Most research focuses on online identity construction in social media in Western contexts [7]; [8]; [5]). There has not been much research on online identity in the context of Indonesian social media.

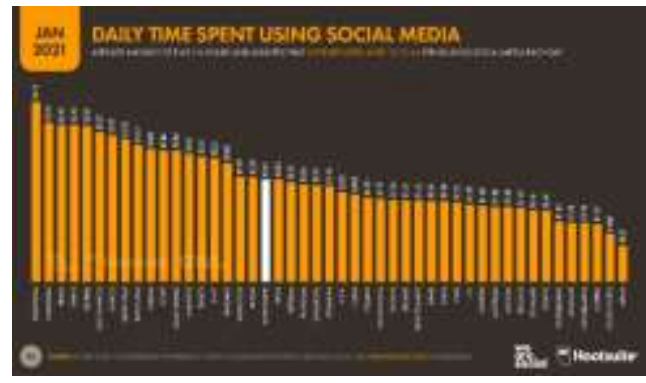

Figure 1 Time spent on social media. 


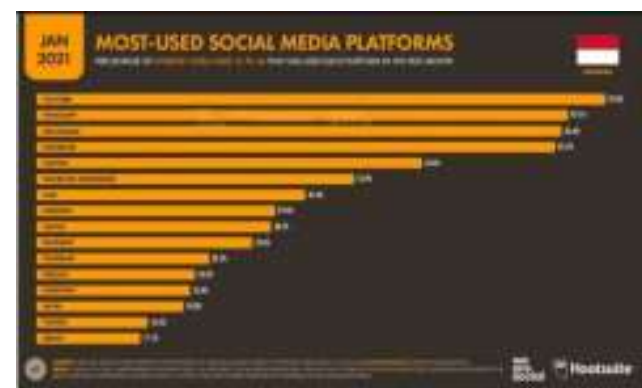

Figure 2 Use of social media in Indonesia.

Based on Figure 1, the results of Hootsuite 2021 research, the time spent by Indonesian people on social media is in the top 9 positions in the world and for the last 5 years Indonesia's ranking has never been outside the top 10. This means that Indonesia's social media users are a large number, coupled with a large population. Based on Figure 2, Instagram is one of the top three most used social media in Indonesia.

Several studies have confirmed the differences between offline and online self-presentation. When compared to offline self-presentation, self-identity from online presentation projections is built from "nothingness" [9]; [6]. This is following Erving Goffman's front-stage and backstage concepts in drama [10]; [11]. What we see in front of the stage may be different from what we will see at the back stage. In the context of social media, this is very possible because identity on social media is not only about who we are but also how other people expect and who we want for others [1].

Social media users in Indonesia have various strategies to build their online identity. The visual, narrative and self-labelling practices of social media users in Indonesia are also different. Not infrequently creative words appear from social media users in Indonesia. Social media in this study is limited to Instagram. Instagram is a social media that is quite popular in Indonesia [12]. Instagram provides a space for self-presentation through a combination of images, videos, and words. Instagram users are also quite large by occupying the top 3 most used social media in Indonesia. Therefore, the direction of this research is to 1) describe the strategies of Indonesian social media users to build their online identity, 2) describe the visual, narrative, and self-labelling practices of Indonesian Instagram social media users, and 3) describe the forms of creative words that appear on Indonesian social media.

\section{METHOD}

This research utilizes a qualitative technique to describe strategies for building an online identity, as well as visual, enumerative, and self-labelling practices and creative words. The data for this study was collected from Instagram of Indonesian celebrities that met the requirements. 1) Male and female, 2) youthful and adult age, 3) Indonesian Instagram active users with more than 1 million followers. It is thought to be able to represent Instagram social media users with influence in Indonesia and become a "dream" for Instagram social media users in Indonesia based on these criteria. The data of this research are transcripts of speeches, words, and videos of Indonesian celebrities on Instagram social media.

The data is subsequently processed and analyzed following the study's objectives. Instagram is a social networking platform that allows users to make 'regular' posts and instastory posts. Both of these features can be filled with publicly visible images, audio, or videos. The difference is that instastory postings are deleted after 24 hours, whereas regular posts are not. Data analysis was performed on the data collected from these two Instagram features to see how Instagram social media users used the two Instagram features to develop their identities. Data from these two aspects were also examined to discover visual, enumerative, and selflabelling habits among Instagram users. Finally, all the data collected is analyzed and sorted to find creative words that appear.

\section{ANALYSIS}

\subsection{The Strategy of Indonesian Instagram Social Media Users to Build an Online Identity}

Based on the research results, the strategies of Instagram social media users to build online identities can be divided based on the media and content. Based on the media, it can be seen in the following figure.

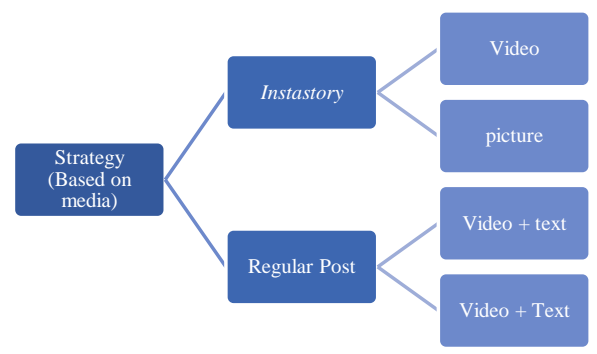

Figure 3 Instagram Social Media User Strategy

Building an Online Identity Based on the Media used

Instagram users, as shown in the figure above, use two types of media to build their online identities: Instastory and regular posts. Instagram invented Instastory as a way for people to share their daily activities in the form of photographs or videos that are only 15-20 seconds long and only last for 24 hours [13]. Regular Instagram posts are media given by Instagram for users to share their everyday activities in the form of text, pictures, or videos, and they do not disappear after 24 hours (saved). 
Instagram social media users use Instagram stories and regular posts to build their online identity. The celebgrams who are the source of the research data are very active in using both media on Instagram. On average, in 24 hours, they use Instagram stories more than 30 times, some even more than 70 times in the form of images or videos. The use of regular posting media is also very active. Almost all the subjects of this study used regular posting media every day, with an average of 4 posts a day, in the form of images and videos accompanied by text.

Based on its contents, the strategy of Instagram social media users to build online identity can be seen in the following figure.

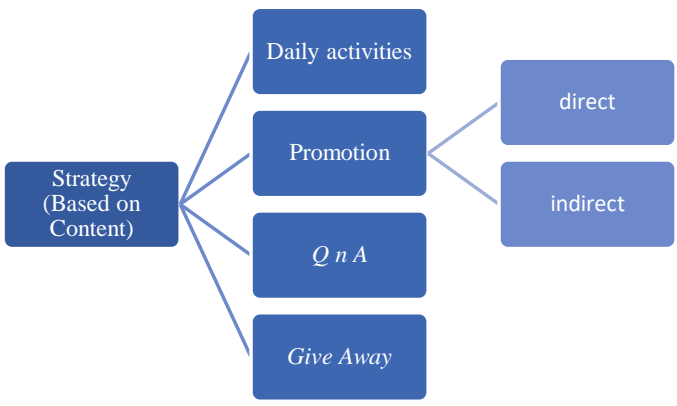

Figure 4 Strategies for Instagram Social Media Users to Build an Online Identity Based on the Content

According to the findings, Instagram users in Indonesia build online identities using a variety of post content, such as daily activities, promotions, Q\&A, and giveaways. This method is used by the source of this research data, who can be considered a celebrity. The daily activities that are posted are their daily activities, which might range from artists' daily activities to successful professionals' daily activities to their family lives. They're also very active on Instagram, especially on Instastory, where they share a lot of promotional content. This advertisement is out via both direct and indirect strategies. The direct strategy is implemented by declaring openly that the post is a promotion. Indirect promotional activities are those that are carried out behind the scenes and are disguised as other activities, such as sharing videos of other people's shipments of goods.

Instagram social media users also carry out strategies to increase and maintain the number of followers by involving active followers interacting directly. The strategies implemented include QnA and Give Away. QnA is a feature on Instagram so that account owners and followers can interact directly with account owners, asking followers questions in the "ask me something" column, then followers can respond in the "type something" column. Give Away is an activity to distribute prizes with certain conditions. Each participant who takes part in the giveaway must and must fulfil every requirement following the holding of the give away event. Starting from enlivening a post, to making certain challenges.

\subsection{Visual, Narrative, and Self-labeling Practices}

The forms of visual, enumerative, and self-labeling practices of Instagram social media users in building online identities may be observed in the following table, which is based on the research findings:

\begin{tabular}{|c|c|c|c|}
\hline Source & $\begin{array}{c}\text { Visual } \\
\text { Practice }\end{array}$ & Impression & $\begin{array}{c}\text { Self } \\
\text { Labeling }\end{array}$ \\
\hline \multirow{5}{*}{$\begin{array}{l}\text { S (Subject) } \\
1 \quad \text { Image } \\
\text { and Video } \\
\text { Instastory }\end{array}$} & Open Eid gifts & Irv lot & \multirow{5}{*}{$\begin{array}{l}\text { Hard } \\
\text { worker, } \\
\text { success } \\
\text { with work }\end{array}$} \\
\hline & & frie & \\
\hline & Happy $\quad$ Eid & friendly & \\
\hline & Greetings & & \\
\hline & Advertisement & Interesting & \\
\hline \multirow{2}{*}{$\begin{array}{l}\text { S (Subject) } \\
2 \text { Images } \\
\text { and } \\
\text { Instastory } \\
\text { Videos }\end{array}$} & $\begin{array}{l}\text { Filling } \\
\text { shows }\end{array}$ & $\begin{array}{l}\text { Prestigious, } \\
\text { glamorous }\end{array}$ & \multirow{2}{*}{$\begin{array}{l}\text { Hard } \\
\text { worker, } \\
\text { successful } \\
\text { with work } \\
\text { beautiful } \\
\text { (body goal) }\end{array}$} \\
\hline & selfie & $\begin{array}{l}\text { Narcissistic, } \\
\text { confident }\end{array}$ & \\
\hline \multirow{2}{*}{$\begin{array}{l}\text { S (Subject) } \\
3 \text { Images } \\
\text { and } \\
\text { Instastory } \\
\text { Videos } \\
\end{array}$} & $\begin{array}{l}\text { Sharing Eid } \\
\text { allowances }\end{array}$ & $\begin{array}{l}\text { Generous, } \\
\text { lot of money }\end{array}$ & \multirow{2}{*}{$\begin{array}{l}\text { Generous, } \\
\text { success } \\
\text { with work }\end{array}$} \\
\hline & Advertisement & Interesting & \\
\hline $\begin{array}{l}\text { S (Subject) } \\
4 \text { Images } \\
\text { and Videos } \\
\text { Regular } \\
\text { posts }\end{array}$ & $\begin{array}{l}\text { Photos with } \\
\text { children, } \\
\text { photos of } \\
\text { children's } \\
\text { activities, photo } \\
\text { shoots with } \\
\text { children }\end{array}$ & $\begin{array}{l}\text { Luxury, } \\
\text { motherhood, } \\
\text { happy family }\end{array}$ & $\begin{array}{l}\text { family } \\
\text { goal, dream } \\
\text { mother }\end{array}$ \\
\hline
\end{tabular}

Table 1 Forms of Visual Practices, Impressions, and Self Labeling of Instagram Social Media Users.

According to table 1, everyone engages in a variety of visual, enumerative, and self-labelling practices. Each person's visual practice is different, and thus the ensuing impression is different as well. At the end of the day, everyone's self-labelling is unique. However, there are some parallels between the events in table 1 and those in table 2. They all have their unique appeal that attracts a large number of fans. However, according to Erving Goffman's concept of front stage and backstage, the online identity in self-labelling of Instagram social media users can be distinct from the "real" identity [14]; [15]; [11].

S3, for example, shows a visual practice of sharing Eid allowances and advertising in his instastory. Eid allowances are distributed to followers in the form of a big quantity of IDR 100,000 in denominations. The overall impression is one of wealth and abundance. Another activity is to advertise regularly. This activity gives the idea that $\mathrm{S} 3$ is a diligent worker and successful with a job that includes a lot of advertisements, in addition to S3's commercial activities. 


\subsection{Creative Words That Appear}

The following table shows the creative words that appear on Instagram social media, based on the study's findings:

\begin{tabular}{|c|c|c|c|c|}
\hline $\begin{array}{l}\mathbf{N} \\
\mathbf{0}\end{array}$ & $\begin{array}{c}\text { Catego } \\
\text { ry }\end{array}$ & Type & Example Words & $\begin{array}{c}\text { Informati } \\
\text { on }\end{array}$ \\
\hline \multirow[t]{4}{*}{1} & \multirow[t]{4}{*}{$\begin{array}{l}\text { abbrevi } \\
\text { ation }\end{array}$} & Vowels & $\begin{array}{l}\text { kl (kalau) <if>, n } \\
\text { (dan) <and>, yg } \\
\text { (yang) <which>, sm } \\
\text { (sama) < with>, bgt } \\
\text { (banget) < very> }\end{array}$ & $\begin{array}{l}\text { Vowels } \\
\text { removed }\end{array}$ \\
\hline & & $\begin{array}{l}\text { Conson } \\
\text { ant }\end{array}$ & $\begin{array}{l}\text { Ka (kak) } \\
<\text { brother/sister>, } \\
\text { bobo (bobok) < } \\
\text { sleep > }\end{array}$ & $\begin{array}{l}\text { omitted } \\
\text { consonants }\end{array}$ \\
\hline & & Mixture & $\begin{array}{lr}\text { cwo } & \text { (cowok) } \\
<\text { brother>, } & \text { cwe } \\
\text { (cewek) } \quad \text { <ister>, } \\
\text { gapapa (gak apa- } \\
\text { apa) < nothing > }\end{array}$ & $\begin{array}{l}\text { Vowels } \\
\text { and } \\
\text { consonants } \\
\text { are } \\
\text { randomly } \\
\text { removed } \\
\end{array}$ \\
\hline & & $\begin{array}{l}\text { Substitu } \\
\text { tion }\end{array}$ & $\begin{array}{l}\text { w (gue) <me>, } \\
\text { sampe (sampai) }< \\
\text { arrive>, pake } \\
\text { (pakai) }<\text { use }>\end{array}$ & $\begin{array}{l}\text { The } \\
\text { majority of } \\
\text { diphthongs }\end{array}$ \\
\hline \multirow[t]{2}{*}{2} & \multirow{2}{*}{\multicolumn{2}{|c|}{ Addition }} & $\begin{array}{l}\text { Seringggg (often), } \\
\text { rinduuu (miss you) }\end{array}$ & Emphasis \\
\hline & & & 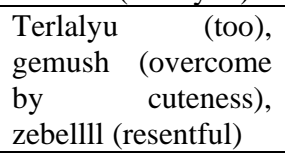 & $\begin{array}{l}\text { Funny, } \\
\text { coquettish }\end{array}$ \\
\hline 3 & \multicolumn{2}{|c|}{ Acronym } & $\begin{array}{lr}\text { Buber } & \text { (buka } \\
\text { bersama) } & <\text { breaking } \\
\text { the fast } & \text { together>, } \\
\text { nobar } & \text { (nonton } \\
\text { bareng) } & \text { <watch } \\
\text { together> } & \\
\end{array}$ & \\
\hline 4 & \multicolumn{2}{|c|}{$\begin{array}{l}\text { Cultural } \\
\text { Acculturation }\end{array}$} & $\begin{array}{l}\text { Aje <just>, didioain } \\
<\text { be prayed for }>\text {, } \\
\text { nyariin <look for }>\text {, } \\
\text { jogetin <dance>, } \\
\text { temuin <find }>\end{array}$ & $\begin{array}{l}\text { Betawi } \\
\text { language }\end{array}$ \\
\hline
\end{tabular}

Table 2 Creative Words that Appear in Instagram Social Media.

On the social media platform Instagram, a variety of creative words appear. Abbreviations, additions, acronyms, and cultural acculturation are the four kinds of creative words that appear in table 2 above. Vowels (omitted vowels), consonants (omitted consonants), mixed (vowels and consonants are abbreviated at random), and substitution are the different types of abbreviations (the majority of diphthongs sound). The creative words that emerge on the social media platform Instagram are distinct and are updated regularly [16].

Pay attention to the additional creative words that appear below.

"Yeah, I oftennnnn (seringggg) see you having dinner at the Plaza Senayan Lounge" (S4/Instastory)
The creative word for adding letters to a word comes oftennnn (seringggg) in examples like the one above. S4 uploaded the text on Instastory as a comment column. The author often observes S4 eating supper at the Plaza Senayan Lounge, hence the word creative is often used to highlight the emphasis.

\section{REFERENCES}

[1] Santoso, A. (2019). Panorama Studi Wacana Kritis: Relasi antara Wacana Publik, Ideologi, dan Kesadaran Berbahasa Kritis. Malang: Universitas Negeri Malang.

[2] Thornborrow, J. (2015). The Discourse of Public Participation Media: From Talkshow to Twitter. New York: Routledge.

[3] Feng, B., Li, X., \& Lin, L. (2021). Valenced Social Identities and the Digital Divide in Online Health Communities. Computers in Human Behavior, 122, 106812 .

[4] Latif, K., Weng, Q., Pitafi, A. H., Ali, A., Siddiqui, A. W., Malik, M. Y., \& Latif, Z. (2021). Social comparison as a double-edged sword on social media: The role of envy type and online social identity. Telematics and Informatics, 56, 101470.

[5] Sirola, A., Kaakinen, M., Savolainen, I., Paek, H. J., Zych, I., \& Oksanen, A. (2021). Online identities and social influence in social media gambling exposure: A four-country study on young people. Telematics and Informatics, 60 , 101582. https://doi.org/10.1016/j.tele.2021.101582

[6] Yuan, Z. min. (2018). Exploring Chinese college students' construction of online identity on the Sina Microblog. Discourse, Context and Media, $26,43-51$.

[7] Idowu, A., \& Elbanna, A. (2021). Crowdworkers, social affirmation and work identity: Rethinking dominant assumptions of crowdwork. Information and Organization, 100335.

[8] Savolainen, I., Oksanen, A., Kaakinen, M., Sirola, A., Zych, I., \& Paek, H.-J. (2021). The role of online group norms and social identity in youth problem gambling. Computers in Human Behavior, 122, 106828.

[9] Cover, R. (2016). Understanding Identity Online: Social Networking. In Digital Identities (pp. 127). Elsevier.

[10] Johansson, C. (2007). Goffman's sociology: An inspiring resource for developing public relations theory. Public Relations Review, 33(3), 275-280. https://doi.org/10.1016/j.pubrev.2007.05.006

[11] Mueller, F. (2018). Taking Goffman seriously: Developing Strategy-as-Practice. Critical Perspectives on Accounting, 53, 16-30. 
[12] Mahardika, R. D., \& Farida, F. (2019). Pengungkapan Diri pada Instagram Instastory. Jurnal Studi Komunikasi (Indonesian Journal of Communications Studies), 3(1), 101.

[13] Kusyanti, A., Ayu Catherina, H. P., \& Lia Sari, Y. A. (2019). Empirical study of \#instastory. Procedia Computer Science, 161, 756-764. Elsevier

B.V. https://doi.org/10.1016/j.procs.2019.11.180

[14] Barnes, M. (2019). Australian Journal of Applied Linguistics Educational Social Media Tools: Promoting Student Investment and Language Identity in the Midst of Digital Surveillance. Australian Journal of Applied Linguistics, 2(2), 47-60. https://doi.org/10.29140/ajal.v2n2.159

[15] Gulatee, Y., Combes, B., \& Yoosabai, Y. (2021). Social Media among Thai Students: Narcissism, Self-Identity or Empowerment? Higher Education Studies, 11(1), 79-93.

[16] Jenkins, E. M., Zaher, Z., Tikkanen, S. A., \& Ford, J. L. (2019). Creative identity (re)Construction, creative community building, and creative resistance: A qualitative analysis of queer ingroup members' tweets after the Orlando Shooting. Computers in Human Behavior, 101, 14-21. 